\title{
Amycolatopsis taiwanensis sp. nov., from soil
}

Correspondence

Min Tseng

tjm@firdi.org.tw

\author{
Min Tseng, ${ }^{1}$ Shu-Feng Yang, ${ }^{1}$ Wen-Jun $\mathrm{Li}^{2}$ and Cheng-Lin Jiang ${ }^{2}$ \\ 'Bio-resource Collection and Research Center, Food Industry Research and Development \\ Institute, HsinChu, 300, Taiwan \\ ${ }^{2}$ Yunnan Institute of Microbiology, Yunnan University, Kunming, Yunnan, 650091, People's \\ Republic of China
}

The genus Amycolatopsis was first described by Lechevalier et al. (1986) and at the time of writing comprises 27 recognized species. Members of the genus are aerobic, Grampositive, non-acid-fast, non-motile organisms that form a branched substrate mycelium that fragments into squareshaped elements. Aerial hyphae may be sterile or differentiate into long chains of spore-like structures. Amycolatopsis species contain meso-diaminopimelic acid (meso- $\left.\mathrm{A}_{2} \mathrm{pm}\right)$, arabinose and galactose in the cell wall (wall chemotype IV of Lechevalier \& Lechevalier, 1970), are rich in iso- and anteiso-branched fatty acids and contain di-, tetra- and hexahydrogenated menaquinones with nine isoprene units as the predominant isoprenologue. Phosphatidylethanolamine (PE) and phosphatidylglycerol are major polar lipids with diphosphatidylinositol mannosides variably present. Members of the genus have DNA $\mathrm{G}+\mathrm{C}$ contents in the range $66-73 \mathrm{~mol} \%$.

During our investigation of the ecology of novel actinomycetes, we isolated several new strains from soils in Taiwan. In this study, we describe one isolate, $0345 \mathrm{M}-7^{\mathrm{T}}$, as belonging to the genus Amycolatopsis. On the basis of the polyphasic data presented, we propose that strain $0345 \mathrm{M}-7^{\mathrm{T}}$ should be classified within a novel species of the genus Amycolatopsis.

Strain $0345 \mathrm{M}-7^{\mathrm{T}}$ was isolated from a soil sample collected from Yilan county, Taiwan, by using HV agar (Hayakawa \& Nonomura, 1987), and incubated at $28^{\circ} \mathrm{C}$ for 4 weeks. The

\footnotetext{
Abbreviations: $\mathrm{A}_{2} \mathrm{pm}$, diaminopimelic acid; PE, phosphatidylethanolamine.

The GenBank/EMBL/DDBJ accession number for the 16S rRNA gene sequence of strain $0345 \mathrm{M}-7^{\top}$ is DQ160215.
}

strain was maintained on oatmeal agar and stored at $-20{ }^{\circ} \mathrm{C}$ as a suspension of spores or mycelial fragments in $20 \%(\mathrm{v} / \mathrm{v})$ glycerol.

Morphological characteristics of cells of strain $0345 \mathrm{M}-7^{\mathrm{T}}$ were observed via scanning electron microscopy (S-420; Hitachi), following incubation on HV agar for 14 days at $28{ }^{\circ} \mathrm{C}$ and fixation in $4 \%$ osmium tetroxide solution, dehydration through a graded ethanol series and acetone, followed by critical-point drying. Cultural characteristics were tested by using 14-day-old cultures grown at $28^{\circ} \mathrm{C}$ on various agar media (Table 1). Colour designations of the substrate mycelium were according to Kelly (1964). All physiological tests were performed at $28^{\circ} \mathrm{C}$. Growth temperature, $\mathrm{NaCl}$ tolerance, hydrolysis of aesculin, casein, gelatin, hypoxanthine and xanthine and production of amylase, nitrate reductase and urease were tested following the methods and procedures of Gordon et al. (1974). Carbon source utilization was examined on ISP 9 as the basal medium (Shirling \& Gottlieb, 1966) supplemented with a final concentration of $1 \%$ of the tested carbon source.

Biomass for chemotaxonomic studies was prepared following growth in shaking flasks (125 r.p.m.) of YG broth $(10.0 \mathrm{~g}$ yeast extract and $10.0 \mathrm{~g}$ glucose per litre distilled water, $\mathrm{pH} 7 \cdot 0$ ) at $28^{\circ} \mathrm{C}$ for 7 days. The isomer of $\mathrm{A}_{2} \mathrm{pm}$ and sugars in whole-cell hydrolysates were determined by the method of Hasegawa et al. (1983). The $\mathrm{N}$-acyl types of muramic acid were determined by the method of Kawamoto et al. (1981). Presence of mycolic acids was examined via TLC following Minnikin et al. (1975) and phospholipids were extracted and identified following the method of Minnikin et al. (1984). Menaquinones were extracted and purified according to the method of Collins 
Table 1. Cultural characteristics of strain $0345 \mathrm{M}-7^{\top}$

Mycelium colours were taken from Kelly (1964).

\begin{tabular}{|lccc|}
\hline Medium & Growth & Substrate mycelium & Sporulation \\
\hline Tryptone-yeast extract agar (ISP 1) & Good & Purple-yellow & None \\
Yeast extract-malt extract agar (ISP 2) & Good & Light yellow & None \\
Oatmeal agar (ISP 3) & Good & Yellowish white & Poor \\
Inorganic salts-starch agar (ISP 4) & Good & Yellowish white & Poor \\
Glycerol-asparagine agar (ISP 5) & Good & Purple-yellow & Poor \\
Glucose-asparagine agar & Poor & Yellowish white & Poor \\
Peptone-yeast-iron agar (ISP 6) & Good & Light yellow & None \\
Tyrosine agar (ISP 7) & Good & Light yellow & Poor \\
Glucose-asparagine agar & Poor & Yellowish white & Poor \\
Bennett's agar & Poor & Light yellow & None \\
Nutrient agar & Poor & Light yellow & None \\
\hline
\end{tabular}

et al. (1977) and then analysed by HPLC (model 600; Waters) with a Nova-Pak C18 column. For quantitative analysis of the cellular fatty acid content, strain $0345 \mathrm{M}-7^{\mathrm{T}}$ was cultured using TSB medium at $28^{\circ} \mathrm{C}$ on a shaking incubator at 125 r.p.m. for 7 days. Extracts of the methylated fatty acids were prepared according to the protocol provided by MIDI Inc.

For the extraction of DNA to be used for sequencing of the $16 \mathrm{~S}$ rRNA gene, strain $0345 \mathrm{M}-7^{\mathrm{T}}$ was grown in YG broth at $28^{\circ} \mathrm{C}$ for 7 days. Cells were removed from the broth using a pipette tip and total DNA was extracted by using the QIAGEN Genomic DNA kit. The G + C content of the DNA was determined by HPLC according to the method of Tamaoka \& Komagata (1984). DNA was prepared by using the same method as above. The 16S rRNA gene was PCRamplified according to the methods of Nakajima et al. (1999) and directly sequenced on an ABI model 3730 automatic DNA sequencer using the BigDye Terminator v3.1 kit (Applied Biosystems). Phylogenetic analysis was performed using the software packages PHYLIP (Felsenstein, 1993) and MEGA version 2.1 (Kumar et al., 2001) after multiple alignment of data by using CLUSTAL X (Thompson et al., 1997). Calculation of evolutionary distances (distance options according to the Kimura two-parameter model; Kimura, 1980, 1983) and clustering were with the neighbour-joining method (Saitou \& Nei, 1987). Bootstrap analysis was used to evaluate the tree topology of the neighbour-joining data by performing 1000 resamplings (Felsenstein, 1985).

Strain $0345 \mathrm{M}-7^{\mathrm{T}}$ produced branched and non-fragmented substrate mycelia, borne on which were short spore chains. No aerial mycelia were found after growth on any of the test media. Spores were non-motile, oval and smooth-surfaced (Fig. 1). The cultural characteristics of strain $0345 \mathrm{M}-7^{\mathrm{T}}$ are detailed in Table 1. Good growth and pale-yellow substrate mycelia were observed but sporulation was poor on most of the media tested. No soluble pigment was produced in all media tested. The physiological and biochemical characteristics of strain $0345 \mathrm{M}-7^{\mathrm{T}}$ are given in Table 1 and in the species description below.
Strain $0345 \mathrm{M}-7^{\mathrm{T}}$ contained meso- $\mathrm{A}_{2} \mathrm{pm}$, arabinose, galactose, glucose and ribose in whole-cell hydrolysates. The predominant menaquinone was MK- $9\left(\mathrm{H}_{4}\right)$; mycolic acids were not detected. PE was detected. The major fatty acid methyl esters were iso- $\mathrm{C}_{16: 0}(38 \cdot 1 \%), \mathrm{C}_{17: 1}(25 \cdot 4 \%)$, anteiso- $\mathrm{C}_{17: 0}(5 \cdot 2 \%), \mathrm{C}_{16: 0}(5 \cdot 1 \%)$ and $\mathrm{C}_{17: 0}(4 \cdot 0 \%)$, but tuberculostearic acid was not detected. The $\mathrm{G}+\mathrm{C}$ content of the DNA was $68.9 \mathrm{~mol} \%$.

The almost-complete 16S rRNA gene sequence (1507 nt) of strain $0345 \mathrm{M}-7^{\mathrm{T}}$ was determined. Preliminary comparison of the sequence against the GenBank database revealed high sequence similarity values with members of the genus Amycolatopsis. The phylogenetic tree based on the 16S rRNA gene sequences of strain $0345 \mathrm{M}-7^{\mathrm{T}}$ and recognized members of the genus Amycolatopsis is shown in Fig. 2. Strain 0345M$7^{\mathrm{T}}$ had 16S rRNA gene similarity values ranging between 92.7\% (Amycolatopsis fastidiosa IMSNU 20054 ${ }^{\mathrm{T}}$ ) and

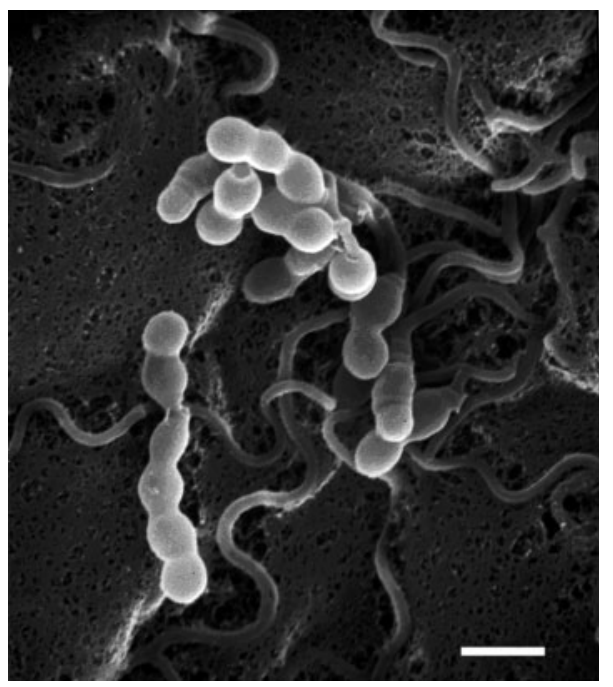

Fig. 1. Scanning electron micrograph of cells of strain $0345 \mathrm{M}-$ $7^{\top}$ grown on $\mathrm{HV}$ agar for 14 days at $28^{\circ} \mathrm{C}$. Bar, $1.5 \mu \mathrm{m}$. 


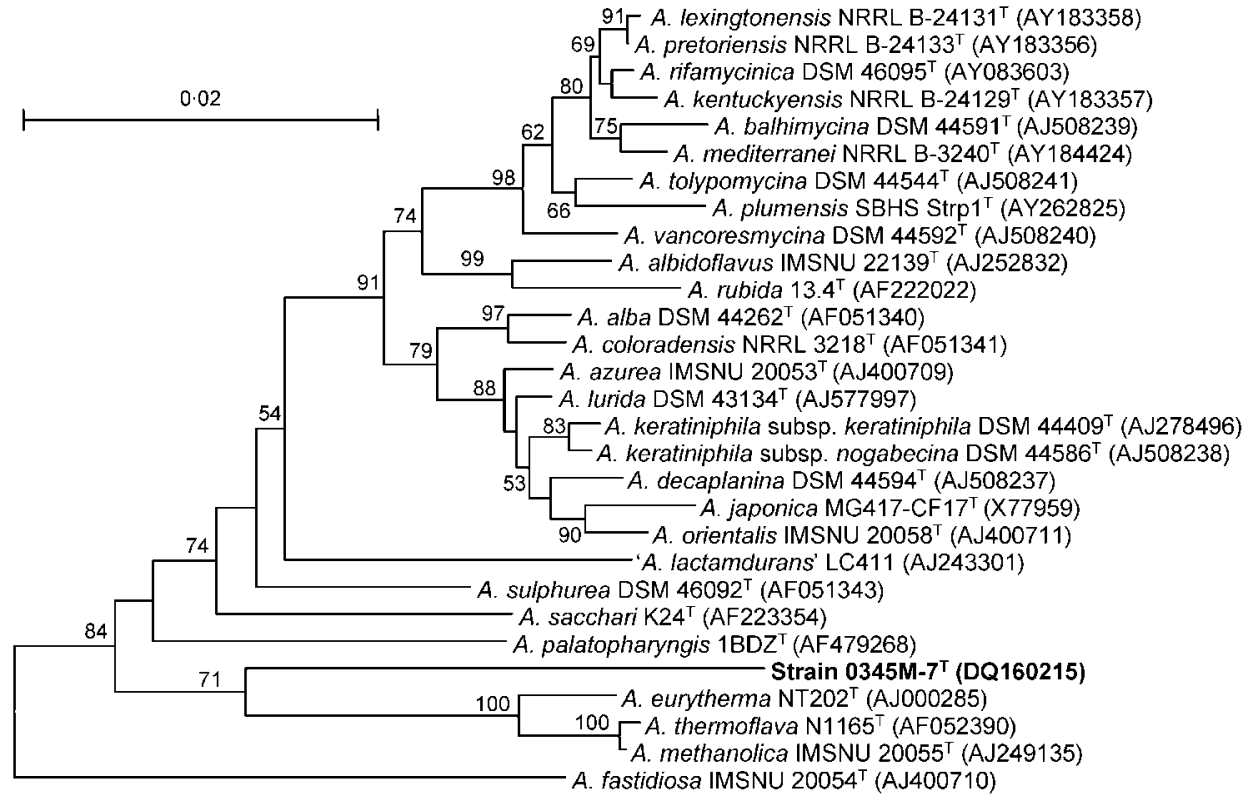

Fig. 2. Neighbour-joining tree (Saitou \& Nei, 1987) based on almost-complete 16S rRNA gene sequences showing the phylogenetic position of strain $0345 \mathrm{M}-7^{\top}$ within the radiation of Amycolatopsis species. Numbers at nodes indicate percentages of 1000 bootstrap resamplings; only values $>50 \%$ are given. Bar, 0.02 substitutions per nucleotide position.

Table 2. Characteristics that differentiate strain $0345 \mathrm{M}-7^{\top}$ from its nearest phylogenetic neighbours

Strains: 1, strain $0345 \mathrm{M}-7^{\mathrm{T}} ; 2$, Amycolatopsis eurytherma DSM $44348^{\mathrm{T}} ; 3$, Amycolatopsis methanolica IMSNU $20055^{\mathrm{T}} ; 4$, Amycolatopsis thermoflava IFO $14333^{\mathrm{T}}$. Data for reference strains were taken from Chun et al. (1999) and Kim et al. (2002). +, Positive; -, negative; W, weak growth or reaction; ND, no data available. For all four strains, the cell-wall peptidoglycan contains meso- $\mathrm{A}_{2} \mathrm{pm}$ and mycolic acids are absent.

\begin{tabular}{|c|c|c|c|c|}
\hline Characteristic & 1 & 2 & 3 & 4 \\
\hline Presence of aerial mycelium & - & + & + & + \\
\hline Spores on substrate hyphae & + & - & - & - \\
\hline Production of soluble pigment & - & - & - & + \\
\hline Growth at $5 \% \mathrm{NaCl}(\mathrm{w} / \mathrm{v})$ & - & + & + & + \\
\hline Growth at $45^{\circ} \mathrm{C}$ & - & + & + & + \\
\hline \multicolumn{5}{|l|}{ Decomposition of: } \\
\hline Aesculin & + & - & $\mathrm{W}$ & + \\
\hline Casein & + & + & - & + \\
\hline Gelatin & + & + & + & - \\
\hline Hypoxanthine & $\mathrm{w}$ & $\mathrm{W}$ & + & + \\
\hline Xanthine & - & - & - & + \\
\hline \multicolumn{5}{|l|}{ Production of: } \\
\hline Amylase & - & ND & - & - \\
\hline Nitrate reductase & + & + & + & - \\
\hline Urease & - & + & - & + \\
\hline Polar lipids* & $\mathrm{PE}$ & $\begin{array}{l}\text { DPG, PE, PI, } \\
\text { PIM, PME, PL }\end{array}$ & DPG, PE & ND \\
\hline
\end{tabular}

${ }^{*}$ DPG, Diphosphatidylglycerol; PE, phosphatidylethanolamine; PI, phosphatidylinositol; PIM, phosphatidylinositol mannosides; PL, unidentified polar lipid; PME, phosphatidylmonomethylethanolamine. 
95.4\% (Amycolatopsis methanolica IMSNU $20055^{\mathrm{T}}$ ). It is generally recognized that organisms displaying similarity values of $<97 \%$ do not belong to the same species (Stackebrandt \& Goebel, 1994). The sequence divergence values of $>4.0 \%$ with recognized members of the genus Amycolatopsis clearly indicate that strain $0345 \mathrm{M}-7^{\mathrm{T}}$ represents a novel species.

Morphologically, species of the genus Amycolatopsis have not previously been described to form short spore chains on mature substrate mycelia and without the formation of aerial mycelia. These morphological features have been described for members of the genus Catellatospora (Asano \& Kawamoto, 1986). However, chemotaxonomic data, including the predominant menaquinone, polar lipid and major fatty acids, indicate that strain $0345 \mathrm{M}-7^{\mathrm{T}}$ should be classified within the genus Amycolatopsis.

The distinctiveness of the isolate is also shown by phenotypic comparison with its nearest phylogenetic neighbours (Table 2). On the basis of the phenotypic and genotypic data presented, $0345 \mathrm{M}-7^{\mathrm{T}}$ should be classified as the type strain of a novel species of the genus Amycolatopsis, for which the name Amycolatopsis taiwanensis sp. nov. is proposed.

\section{Description of Amycolatopsis taiwanensis sp. nov.}

Amycolatopsis taiwanensis (tai.wan.en'sis. N.L. fem. adj. taiwanensis of Taiwan, where the type strain was isolated).

Gram-positive, aerobic, non-acid-fast and mesophilic. No aerial mycelia are present. Short spore chains are formed on substrate mycelia; spores are oval with a smooth surface and are non-motile. The substrate mycelium is yellowish white to purple yellow. No soluble pigment is produced. Growth is good on most test media, but sporulation is very poor. Good growth occurs between 20 and $40{ }^{\circ} \mathrm{C}$; no growth occurs above $1 \% \mathrm{NaCl}$. Hydrolyses casein and aesculin and is positive for gelatin liquefaction. Able to reduce nitrate. Glucose, arabinose, cellulose and sucrose can be used as sole carbon sources for growth, but not fructose or salicin; use of rhamnose, inositol, raffinose, mannitol and xylose is questionable. The cell-wall peptidoglycan contains meso$\mathrm{A}_{2} \mathrm{pm}$; arabinose, galactose, glucose and ribose are detected in whole-cell hydrolysates. The predominant menaquinone is MK-9 $\left(\mathrm{H}_{4}\right)$. Mycolic acids are not detected. The diagnostic phospholipid is PE. Major cellular fatty acids are iso- $\mathrm{C}_{16: 0}$ $(38 \cdot 1 \%)$ and $\mathrm{C}_{17: 1}(25 \cdot 4 \%)$. The $\mathrm{G}+\mathrm{C}$ content of the DNA of the type strain is $68.9 \mathrm{~mol} \%$.

The type strain, $0345 \mathrm{M}-7^{\mathrm{T}} \quad\left(=\mathrm{BCRC} \quad 16802^{\mathrm{T}}=\mathrm{KCTC}\right.$ $\left.19116^{\mathrm{T}}\right)$, was isolated from a soil collected from Yilan county, Taiwan.

\section{Acknowledgements}

This research was supported in part by the Ministry of Economic Affairs, People's Republic of China (project no. 93-EC-17-A-17-R70525). We thank Mr J. H. Chiou for assistance with sample collection.

\section{References}

Asano, K. \& Kawamoto, I. (1986). Catellatospora, a new genus of the Actinomycetales. Int J Syst Bacteriol 36, 512-517.

Chun, J., Kim, S. B., Oh, Y. K. \& 7 other authors (1999). Amycolatopsis thermoflava sp. nov., a novel soil actinomycete from Hainan Island, China. Int J Syst Bacteriol 49, 1369-1373.

Collins, M. D., Pirouz, T., Goodfellow, M. \& Minnikin, D. E. (1977). Distribution of menaquinones in actinomycetes and corynebacteria. J Gen Microbiol 100, 221-230.

Felsenstein, J. (1985). Confidence limits on phylogenies: an approach using the bootstrap. Evolution 39, 783-791.

Felsenstein, J. (1993). PHYLIP - Phylogeny Inference Package, version 3.5c. Distributed by the author. Department of Genome Sciences, University of Washington, Seattle, USA.

Gordon, R. E., Barnett, D. A., Handerhan, J. E. \& Pang, C. H.-N. (1974). Nocardia coeliaca, Nocardia autotrophica, and the nocardin strain. Int J Syst Bacteriol 24, 54-63.

Hasegawa, T., Takizawa, M. \& Tanida, S. (1983). A rapid analysis for chemical grouping of aerobic actinomycetes. J Gen Appl Microbiol 29, 319-322.

Hayakawa, M. \& Nonomura, H. (1987). Humic acid-vitamin agar, a new medium for the selective isolation of soil actinomycetes. J Ferment Technol 65, 501-509.

Kawamoto, I., Oka, T. \& Nara, T. (1981). Cell wall composition of Micromonospora olivoasterospora, Micromonospora sagamiensis, and related organisms. J Bacteriol 146, 527-534.

Kelly, K. L. (1964). Inter-Society Color Council-National Bureau of Standards Color-Name Charts Illustrated with Centroid Colors. Washington, DC: US Government Printing Office.

Kim, B., Sahin, N., Tan, G. Y. A., Zakrzewska-Czerwinska, J. \& Goodfellow, M. (2002). Amycolatopsis eurytherma sp. nov., a thermophilic actinomycete isolated from soil. Int J Syst Evol Microbiol 52, 889-894.

Kimura, M. (1980). A simple method for estimating evolutionary rates of base substitutions through comparative studies of nucleotide sequences. J Mol Evol 16, 111-120.

Kimura, M. (1983). The Neutral Theory of Molecular Evolution. Cambridge: Cambridge University Press.

Kumar, S., Tamura, K., Jakobsen, I.-B. \& Nei, M. (2001). MEGA2: molecular evolutionary genetics analysis software. Bioinformatics 17, 1244-1245.

Lechevalier, M. P. \& Lechevalier, H. A. (1970). A critical evaluation of the genera of aerobic actinomycetes. In The Actinomycetales, pp. 393-405. Edited by H. Prauser. Jena: Gustav Fisher.

Lechevalier, M. P., Prauser, H., Labeda, D. P. \& Ruan, J.-S. (1986). Two new genera of nocardioform actinomycetes: Amycolata gen. nov. and Amycolatopsis gen. nov. Int J Syst Bacteriol 36, 29-37.

Minnikin, D. E., Alshamaony, L. \& Goodfellow, M. (1975). Differentiation of Mycobacterium, Nocardia, and related taxa by thin layer chromatographic analysis of whole-cell methanolysates. J Gen Microbiol 88, 200-204.

Minnikin, D. E., O'Donnell, A. G., Goodfellow, M., Alderson, G., Athalye, M., Schaal, A. \& Parlett, J. H. (1984). An integrated procedure for extraction of bacterial isoprenoid quinines and polar lipids. J Microbiol Methods 2, 233-241.

Nakajima, Y., Kitpreechavanich, V., Suzuki, K. \& Kudo, T. (1999). Microbispora corallina sp. nov., a new species of the genus Microbispora isolated from Thai soil. Int J Syst Bacteriol 49, 1761-1767. 
Saitou, N. \& Nei, M. (1987). The neighbor-joining method: a new method for reconstructing phylogenetic trees. Mol Biol Evol 4, 406-425.

Shirling, E. B. \& Gottlieb, D. (1966). Methods for characterization of Streptomyces species. Int J Syst Bacteriol 16, 313-340.

Stackebrandt, E. \& Goebel, B. M. (1994). Taxonomic note: a place for DNA-DNA reassociation and 16S rRNA sequence analysis in the present species definition in bacteriology. Int J Syst Bacteriol 44, 846-849.
Tamaoka, J. \& Komagata, K. (1984). Determination of DNA base composition by reversed-phase high-performance liquid chromatography. FEMS Microbiol Lett 25, 125-128.

Thompson, J. D., Gibson, T. J., Plewniak, F., Jeanmougin, F. \& Higgins, D. G. (1997). The CLUSTAL_X windows interface: flexible strategies for multiple sequence alignment aided by quality analysis tools. Nucleic Acids Res 25, 4876-4882. 